(2) Open Access Full Text Article

PERSPECTIVES

\title{
Servant leadership: a case study of a Canadian health care innovator
}

\author{
This article was published in the following Dove Press journal: \\ Journal of Healthcare Leadership \\ 15 February 2012 \\ Number of times this article has been viewed
}

\section{Tim H Vanderpyl}

School of Global Leadership, Regent University, Virginia Beach, VA, USA
Correspondence: Tim H Vanderpyl PO Box 26I, Coaldale, Alberta, Canada TIMIM3

Tel + I 403360697 |

Email vanderpyl@gmail.com
Abstract: Both servant leadership and innovation are easier to theorize than to actually implement in practice. This article presents a case study of a Canadian health care executive who led a remarkable turnaround of St Michael's Health Centre, a floundering and almost bankrupt nursing home. In less than 7 years, Kevin Cowan turned around the finances and changed numerous broken relationships into strategic alliances. Under his leadership, St Michael's Health Centre went from being one of the most underperforming health care organizations in Canada, to one of the most innovative. This article describes some of Cowan's strategies and argues that a servant leadership approach has a direct impact on an organization's ability to innovate. As far as the author is aware, this is the first published article on this specific change effort, which presents a unique perspective on the topics of servant leadership and innovation.

Keywords: servant leadership, innovation, Canada, health care, case study

\section{Introduction}

Both servant leadership and innovation are easier to theorize than they are to actually live out or execute. It is much easier to talk about serving or innovating, than it is to actually serve or innovate. Canadians tend to shy away from talking about themselves. Describing this tendency of Canadian leadership, Walker explains, "our style is effective, a quiet exercise of leadership with no flash or ostentation, but charisma. It is solid and trustworthy, humble and collaborative, attentive, and based on values." While not directed at him, this quotation accurately describes Kevin Cowan. This paper adds to the literature on both innovation and servant leadership by presenting a case study of a true Canadian innovator and servant leader who embodies innovative Canadian leadership.

Servant leadership as a leadership theory was originally proposed in an essay written in 1970 by Greenleaf. ${ }^{2}$ In this essay, Greenleaf pondered the leadership of Leo, a character in the mythical story Journey to the East, written by Herman Hesse. Leo is the servant of a group travelling across the desert. He does everything for the travellers, and serves in any way needed. But when Leo disappears, the group realizes that Leo was actually their leader. He led through his serving. Greenleaf pondered this paradox and wrote that the test of servant leadership is to ask "[d]o those served grow as persons; do they, while being served, become healthier, wiser, freer, more autonomous, more likely themselves to become servants?"2 Blanchard and Hodges expanded on Greenleaf's writings and wrote that "servant leaders look at leadership as an act of service." ${ }^{\prime 3}$ Servant leadership is not soft leadership; rather, it is a viable and perhaps necessary form of leadership that can generate exceptional results. This paper 
presents an example of a servant leader and tells the story of the remarkable change effort he led.

Kevin Cowan is the former CEO of St Michael's Health Centre (SMHC) in Lethbridge, Alberta, Canada. From 2001 to 2008, Cowan led an effort that changed this health care organization from one that was underperforming and on the verge of bankruptcy, to a thriving and innovative organization that set numerous precedents in Canadian health care. This article describes the strategies used by Cowan in this change effort. These are not grandiose theories but, rather, simple strategies that have become folklore in the organization. By "simple," I mean that they are practical and attainable to the majority of everyday managers. The simplest strategies are sometimes the most ingenious, when mixed with hard work and an intentional and intelligent methodology for implementing them.

The research for this article was conducted through the author's personal observations of Cowan's legacy and folklore as an employee at SMHC (now Covenant Health) from 2009 to the present. The author interviewed seven former counterparts of Cowan, including the former board chairman and six of Cowan's former direct reports. These interviewees also provided feedback on early drafts of this article. The author reviewed every newspaper article published about Cowan and SMHC in The Lethbridge Herald (the local newspaper) from 2000 to 2008. As far as the author is aware, this is the first published research article describing this change effort. Where possible, publically accessible direct evidence of the information below is cited appropriately.

\section{Background}

\section{Early organizational challenges}

In 1929, the Sisters of St Martha bought an old hospital in the prairie town of Lethbridge, Alberta, Canada and, in 1931, they built St Michael's Hospital on the outskirts of this town. ${ }^{4}$ It was run by the sisters for 56 years, and then turned over to professional managers in 1985 . While originally run on private donations and support, like most Canadian hospitals, it continually became more reliant on government tax dollars. ${ }^{5}$ In this way, St Michael's Hospital found that it slowly forfeited its autonomy as it slowly grew more dependent on government funding to operate. The Catholic hospital also immediately generated an ongoing dispute over the existence of a Catholic hospital in a city with many non-Catholics; a dispute that carried on for many decades. ${ }^{5}$ Further, the provincial government built a new hospital a few blocks away, which enraged another dispute and incited competition that carried on for many decades. This dispute culminated in the demolition of St Michael's Hospital in 1997, against the wishes of its leaders, staff, and many community members.

The Canadian health care system is primarily publicly funded, but relies on many private for-profit and nonprofit health care providers to provide services. These providers are given service contracts by government agencies and provide services within those contracts. By the 1990s, St Michael's Hospital was solely reliant on the provincially funded Chinook Health Region (CHR) for funding. (The CHR merged with all other Alberta health regions to form Alberta Health Services in 2009; this same year, SMHC merged with ten other Catholic health care organizations to form Covenant Health. Cowan initially took on the role of vice president and then consultant in this new organization.) After the hospital was demolished, the organization rebranded itself as SMHC. SMHC took over a nursing home and began forging its identity in seniors care. Partly to pacify the SMHC community supporters, CHR agreed to build a long-term and palliative care facility on the old St Michael's Hospital site, which opened in 2000. CHR then leased it to the SMHC organization with a funding agreement for SMHC to provide services.

Throughout the 1990s, SMHC and CHR continually battled over funding arrangements. SMHC finally appealed to the Alberta Minister of Health to settle this dispute, but he ruled against SMHC in August 1998. ${ }^{6}$ CHR served notice a few weeks later that it was terminating its funding arrangement with SMHC, which would have dissolved the SMHC organization. The SMHC board scrambled to appease CHR leaders and negotiated a suitable arrangement that kept the organization alive. In late 1998, the SMHC board also separated from their long-time chief executive officer (CEO). In an interview before he left, he stated he was relieved to be laid off, and that "I no longer have to put up with a lot of the garbage handed around here the last while." An interim CEO took his place while the board searched for a replacement.

By 2000, SMHC may have been one of the worst places to work in Canada in terms of labor relations, employee morale, and management style. This is a subjective observation but one that was reiterated by a number of people who worked there. In May 2000, the licensed practical nurses (LPNs) and health care aides went on strike at SMHC. Few people at the facility seemed excited about providing seniors care and they longingly dreamed of the days of providing acute care as a renowned hospital. 


\section{The Cowan era}

Cowan originally trained as a registered nurse $(\mathrm{RN})$ in Ontario, Canada. He worked in a number of Ontario hospitals in nursing and nurse management roles in his early career. He also completed a master of health administration degree. Through a personal connection, he was recruited to Drumheller, Alberta, in the mid-1990s to run a rural nonprofit organization that supported people with disabilities. This organization was on the verge of bankruptcy and had numerous staffing, financial, and cultural issues. Cowan led an organizational change effort that changed this organization from a dysfunctional to a thriving one, and his reputation as a change leader grew in the Alberta nonprofit community.

The SMHC board recruited Cowan in late 2000 and he started as CEO in January 2001. SMHC at this time had approximately 300 employees, an annual budget of CAD $\$ 10$ million, and a projected annual deficit of CAD\$350,000. The headline in The Lethbridge Herald (the only local daily newspaper) read "Deficit, upkeep are challenges facing new St Michael's boss," illustrating the tough path ahead of him as the new leader. ${ }^{8}$ SMHC's combative atmosphere filtered into the adversarial relationships with its unions. A few weeks after Cowan started, the local paper published complaints about SMHC from the president of the local nurses' union. ${ }^{9}$

In addition, the staffing models at SMHC were set up in an inefficient manner for the number of residents, layout of the building, and funding arrangements with CHR. It could not maintain its level of staffing without substantial changes. Starting in the fall of 2001, Cowan and the management team began using LPNs and health care aides for some tasks rather than RNs. The RN union took great exception to this and filed hundreds of grievances against SMHC between 2001 and 2002. Cowan and the board of SMHC advanced all of these grievances to a precedent setting arbitration.

The local newspaper continually published reports criticizing Cowan and the management at SMHC. In February 2001, an editorial stated that "the centre is dangerously understaffed, and in a situation like that lives hang in the balance." ${ }^{10}$ In September 2001, regarding the proposed staffing changes, it wrote that "the move will place RNs in professional jeopardy" and quoted the nurses' union leader as saying that "I think what is really offensive is the misrepresentation to the public that St Mike's and the CHR are not acknowledging they are providing lesser or unskilled hands to this vulnerable population." " An LPN took exception to this comment and in a letter to the editor, wrote that "I take offence to her continually telling people that I am an unskilled provider ... there is a place in the medical field for all of us." 12

Aside from the one lonely letter to the editor, there was no positive local media coverage of SMHC from 2000 to 2004. Cowan and the Chairman of the SMHC Board published a letter to the public on October 6, 2001 in The Lethbridge Herald. ${ }^{13}$ The editor forced SMHC to pay to publish this letter. The letter sought to clarify some of the comments and criticisms being made. Shortly after this letter, on November 1, 2001 the nurses' union received a court injunction through the Alberta Court of Queen's Bench. This injunction stopped the staffing changes until an arbitrator could rule on the grievances. The front page of The Lethbridge Herald proclaimed the headline "St Mike's RNs block changes" in a large font. ${ }^{14}$ One story quoted the local union leader as saying that "Quite honestly, we see what's happening in Lethbridge as a beachhead in terms of longterm care policy, so we're doing everything we can because it has consequences for the rest of the province." ${ }^{\prime 5}$ Another biased editor wrote that "the Herald receives calls periodically from the families of patients of St Michael's. Often, those callers complain of inadequate care. Their loved one isn't being bathed regularly or is left to eat a meal alone."16 In December 2001, The Lethbridge Herald labeled this dispute as the most contentious issue of the year in Lethbridge. ${ }^{17}$

\section{Initial progress}

In February 2003, after hearing numerous arguments about the permitted scope of practice for LPNs and the staffing model of SMHC, the arbitrator sided with SMHC in all aspects of the arbitration. This allowed LPNs to work at their full scope of practice ( $72 \%$ of the scope of a RN). This ruling was precedent setting and allowed numerous other Canadian health care organizations to begin using LPNs in their facilities as well. But the arbitrator, while awarding the win to SMHC, described the relationship between the parties as "dysfunctional." In the conclusion of his ruling, he wrote: "Given the time, emotion, and expense which has gone into these proceedings ... I strongly urge the parties to earnestly seek to attain the objective of 'harmonious relationships' set out in the Preamble of the Collective Agreement." 18 While not binding in a legal sense, his observation illustrates the difficulties of leading in this culture. After numerous biased and scathing articles on SMHC in 2001 and 2002, The Lethbridge Herald did not publish a single article about the arbitrator's decision, despite its nationwide impact. It is interesting to note that SMHC did not issue a press release or attempt to broadcast its win. This would have been a great time to publicly flaunt 
the win for Cowan, but he chose not to, an excellent sign that a servant leader was leading SMHC.

In 2002, SMHC developed an independent arm of its organization, the St Michael's Housing Association (SMHA) to build new independent living facilities. SMHA procured funds to build and open Martha's House on the property adjacent to SMHC. This facility required private funding and innovative methods of procuring those funds, and the profits could be used to finance community endeavors that would otherwise not be funded by government initiatives. This facility gave SMHC additional financial stability and lessened its overall dependence on CHR for all funding.

In 2005, Cowan successfully negotiated a package deal to return the Geriatric Community Rehabilitation and Bridges Program as well as the Post Acute Rehabilitation Program to the SMHC organization. In 2008, SMHC built and opened St Therese Villa, a Designated Assisted Living (DAL) facility for seniors. This facility has become a template of seniors care in Alberta and many new DAL facilities in Alberta and Saskatchewan are now modeled after it. It was designed and developed by both SMHC and CHR through a mutual partnership.

The above is only a brief history of the organization, and there are numerous other stories that illustrate the dysfunctional culture Cowan inherited. This was not an easy time, but Cowan began refocusing the organization on the future, while cleaning up the mess of the past. This dichotomous approach was difficult for Cowan both personally and professionally. He was attacked from all sides and often felt like a lonely sailor in a sea of discontent and aggressiveness. The rest of this paper describes specific strategies he used to change this culture while somehow finding time and opportunities to develop two innovative health care facilities that have become oftmimicked standards for seniors care in Western Canada.

\section{Tangible solutions}

Innovation is cumbersome and difficult to implement. After all, if it was easy, everyone would be doing it, and it would not be innovation. It would have been easy for Cowan to give up on innovation when he first started and instead spend the first 5 years of his tenure attempting to fix the culture and focus only on the present. He did not hire expensive consultants, or conduct exhaustive engagement surveys, or release a fancy new training program. Instead, Cowan focused on the present and future simultaneously. He did not reminisce about the past; he focused on the future and what SMHC could become. Cowan used four specific strategies to implement these changes: (1) "get in their face"; (2) "offer to serve, rather than be served"; (3) "weed the garden"; and (4) "give the credit away." These strategies are intertwined with a servant leadership approach and provide anecdotal evidence that authentic servant leadership may be a key to invoking innovative organizational change.

\section{"Get in their face"}

Forging alliances is an essential aspect of positive turbulence. This positive turbulence is needed to forge a climate of innovation that embraces forward-moving change. ${ }^{19}$ Cowan forged these alliances through hundreds of conversations over a cup of coffee. Whether it was an adversarial union leader, an unhappy resident or family member, or a jaded leader at CHR, Cowan's strategy was to "get in their face." When a person first hears this phrase, it sounds slightly offensive (was he trying to pick a fight?), but it becomes more intentional and useful when studied further. Cowan did not avoid his enemies and criticizers; rather, he would find the enemy and sit down with that person over coffee to hear their side. It is easier to hate a nameless enemy "over there," than it is to hate someone sitting in an office sharing coffee with you.

These meetings slowly turned adversarial relationships to amiable ones. Cowan would intentionally spend about $95 \%$ of the time talking about the person and what they needed. He would learn about their interests, their children, their families, and their difficulties. He would not engage in arguments but instead sit and listen to their negative attacks on SMHC. After they tired themselves out with animosity, he would offer to help them with whatever they needed. He did not rely on formal written contracts or rigid meeting agendas. Most of his deals were formed with a handshake and a smile. This strategy also worked with the various unions at SMHC. Cowan intentionally spent time meeting with the union leaders and getting to know them as people. The relationships began to soften and the animosity decreased. They still had disagreements but were able to negotiate those disagreements in a reasonable manner; something SMHC had not been able to do for decades.

A cultural context of care is an essential aspect of innovation..$^{20}$ Genuine care cannot be faked, and must be genuine. Leaders who attempt to fake this will sabotage any credibility they might have, and will stifle potential innovation in their organization. A professional actor actually feels sad, in order to look sad. Amateur actors try to fake being sad. ${ }^{21}$ Likewise, a true servant leader must actually feel empathy for those around them, and truly care. Cowan would not have been able to fake this empathy, and getting in people's faces requires a genuine openness that few leaders are able 
to embody. They may attempt to live it but, like an actor attempting to fake an emotion, they are easily found out. Servant leaders must care, and then not be afraid to spend time showing they care. This caring and collaborative approach is an essential part of any innovative change effort. ${ }^{22}$

\section{"Offer to serve, rather than be served"}

Servant leaders do not talk about themselves; they talk about others and partner with others to achieve great things. Arbuckle noted that "the future of healthcare in the Western world depends not on managers and clinicians going their separate ways, but on partnership in which dialog is the accepted way of acting." ${ }^{23}$ SMHC had spent many years making demands from CHR, but it had failed to form partnerships. It seemed to relish making CHR look bad through sparring in public arenas. SMHC also operated from the view that CHR existed to give SMHC whatever it wanted, rather than SMHC serving CHR. This inverted servant paradigm generated an adversarial relationship. Cowan's servant leadership approach slowly softened the CHR leaders as they found SMHC to be an ally and partner that could help them, rather than an enemy they wanted to shut down.

Cowan asked in nearly every meeting and interaction, "what can I do to make your life easier?" In one example, CHR purchased a retail building and planned to convert it to office and health care space. They publicly professed these plans but then realized the building was not suitable for their needs. This action had cost them approximately US\$1 million of taxpayer dollars, which enraged the citizens of Lethbridge. The CHR leaders called a press conference to explain themselves. Cowan heard about this press conference and, shortly before the conference, offered to put the program and office space in the SMHC building instead. He found a win-win solution, when he could have easily sat back and watched CHR flounder in the press conference. He then recruited the SMHC board chair to sit with the CHR executives - the former enemies of SMHC - to publicly announce their partnership. The city was so shocked to see them working together that the actual story died right there. Cowan's approach in this example is the epitome of servant leadership. Greenleaf wrote that a servant leader "is more likely to persevere and refine his hypothesis on what serves another's highest priority needs than is the person who is leader first and who later serves out of promptings of conscience or in conformity with normative expectations." ${ }^{2}$ Cowan understood this immensely. The norms in the organization Cowan inherited involved fighting first. Cowan flipped that norm and sought to serve first.
One difficulty of servant leadership is the toll it can take on both leaders and followers. The employees at SMHC had grown accustomed to fighting and actually grew frustrated with Cowan when he did not retaliate. They pleaded for him to fight back and defend himself and the organization. But he disregarded their pleas and stubbornly refused to do so. Their frustration eventually grew into admiration, but it took many years to do so. This is not a subtle point to make. Servant leadership is not passive or soft; it may in fact require more fortitude than other types of leadership.

\section{"Weed the garden"}

Health care organizations in Canada typically have a difficult time dealing with problem employees, partly because of the strength of health care unions. Health care leaders tend to shy away from difficult personnel decisions and unions have gained immense power from this timidity. Servant leadership requires a direct and fair method to deal with problem employees. ${ }^{3}$ Servant leaders realize that, sometimes, ill-fitted or ill-performing employees must be "weeded out" of the organization and set up to succeed elsewhere. Sometimes, employees are toxic and simply unable to adapt to changes. It is easy to ignore this and not deal with these employees in change efforts, but Cowan did not do so. He was unafraid to stand his ground when it came to performance issues. He went through numerous arbitrations and paid out severance if he needed to. He did not make excuses for not dealing with these employees, and was one of the most aggressive CEOs in Alberta in dealing with underperforming employees. Gardner calls the willingness to do battle the sine qua non of leadership. ${ }^{24}$ While there are many other aspects of leadership besides fighting, that willingness to fight over essential items is a hallmark of effective leaders.

This focus on personnel is much like Collins' oft-quoted strategy of "first who, then what." 25 Effective leadership requires the fortitude to make tough personnel decisions. Cowan viewed severance payments and legal fees as a legitimate business expense, when weighed against the cost of enabling an underperforming or toxic employee. Cowan's phrase for this was "weeding the garden" and, despite his friendly, supportive, and engaging approach, he had a line that, when crossed, meant that an employee ceased to work for the organization. This required courage, fortitude, and persistence to stand up to a union when an employee was clearly not suitable to work for the organization. Over time, the unions grew to respect his fortitude and consistency, and began negotiating with SMHC rather than fighting it constantly. Costly arbitrations began slowing in frequency and complex issues began to be resolved over coffee rather than in arguments. 


\section{"Give the credit away"}

A hallmark of Cowan's leadership style was that he constantly gave credit away to others around him. He loved bragging about his direct reports and the work they did. De Pree describes the importance of delegation to leaders and that delegates need to be sent and empowered to do their work. ${ }^{26}$ Cowan sent and empowered his direct reports to grow as managers, more than they had in any other role they had done. One manager stated that she had 35 years of experience before Cowan became her supervisor, but that she learned more about leadership in the 5 years she worked under Cowan than in the rest of her career combined. At times, Cowan compensated for his direct reports' weaknesses without complaint and continually sought out ways to give them credit for things they did. In turn, this inspired them to do this with their own direct reports and was a large part of the overall cultural change.

Cowan also found ways to credit his adversaries for their successes. Some took this credit without realizing it was Cowan who gave it to them. This paradox of power is an intriguing aspect of servant leadership. Who is more powerful: the one who chooses to serve another or the one who has no choice but to receive that serving? The giver is usually more powerful than the receiver. While Cowan had limited financial means to give to the $\mathrm{CHR}$, he reconciled the power imbalance by serving the leaders there. In a paradoxical way, Cowan actually gained power over the CHR through his serving.

For example, the former CEO of CHR wanted to shut down SMHC and was not shy in sharing his viewpoints about SMHC. Rather than fight or ignore him, Cowan met with this CEO every chance he could get. At every meeting, this CEO would tell Cowan it was within his power to shut down SMHC if he wanted to. Cowan did not retaliate and sat there listening to these threats in meeting after meeting. After the threats and venting slowed, Cowan would then say, "How can I help you?" After numerous meetings, the CEO realized Cowan was not there to continue the war; he actually wanted to help. He began to soften toward Cowan, and they negotiated mutually beneficial deals that helped both the SMHC and CHR grow. It is entirely possible that had Cowan continued SMHC's adversarial relationship, the CHR would have succeeded in shutting down SMHC. At the very least, CHR would never have considered an innovative partnership that resulted in building St Therese Villa, or transferring new programs to SMHC. Ironically, at this CEO's retirement party, the $\mathrm{CEO}$ claimed that his biggest success was personally fixing the relationship between SMHC and CHR.
A primary way to tell the difference between self-serving leaders and servant leaders is in how they approach succession planning. ${ }^{3}$ Cowan hired a new director of clinical services in 2005 and turned the organization over to this person in 2008. This person was not a $\mathrm{RN}$ and was relatively young for the job, but Cowan had spotted a person he could groom for his position and recruited him anyway. For the first time in the organization's history, the nursing manager was not a nurse. Anders writes about "rare finds" and how leaders need to read resumes upside down to find previously unseen talent; traditional recruiting simply leads to status quo candidates. ${ }^{27}$ Cowan chose not to follow the organization's history of always having a RN managing RNs, and hired an unlikely successor. Cowan then mentored this person with the full intention of one day letting him lead SMHC. When the time came for this leadership transition, he gave his position away to take on other roles in the newly formed Covenant Health. Even though Cowan has kept an office at the SMHC facility while he has worked in various consulting roles, he has not interfered in this new leader's leadership. Rather, he has been a cheerleader and resource for his successor.

\section{Discussion}

Cowan's perseverance revitalized a dysfunctional organization. When Cowan took over the almost bankrupt SMHC in 2001, it had a CAD $\$ 10$ million annual budget, a large deficit, and no capital assets. When he turned it over to his successor in 2008 , the SMHC organization had CAD $\$ 43$ million in capital assets, a CAD $\$ 30$ million annual budget, and an annual surplus. It boasted an emerging culture with amiable labor relations with a workforce that was growing in pride about its work. LPNs might still be working in limited scope if Cowan had not chosen to fight for them. He inspired a new model of seniors care that has become the template for seniors facilities in Western Canada. This facility's design has been praised by numerous dignitaries and recently won an award that recognized its artistic contributions and design. Cowan further honed and perfected an independent living model that has won awards for its approach to customer service. He turned dysfunctional labor relationships into workable and functional ones. He also turned a dysfunctional funding relationship into a thriving alliance.

Cowan's innovative change effort seems incredible but is the modus operandi of any true high-performing servant leader. Servant leaders generate results and turn around organizations not through their charisma or talent, but through their hearts. The aforementioned strategies can be used by any servant leader but require a servant-minded heart first. 
Cowan's legacy also shows the impact servant leadership has on innovation. Innovators do not simply operate in isolation; they thrive in environments that focus on solutions, not credit. Even Thomas Edison required a team to inspire, test, and follow through on his innovations.

\section{Conclusion}

Innovation and change rarely happen without a cost. Ford wrote that "to choose the path of leadership is to be on a collision course with conflict." ${ }^{28}$ Cowan was verbally attacked in numerous public and private meetings and struggled greatly to implement these change efforts. Oster writes that "innovation requires immense courage ... the position of innovation leader is complex, difficult, frustrating, politically dangerous, and often without thanks. ${ }^{29}$ Cowan fits this description perfectly. Innovators will face setbacks and failures but somehow they persevere to see their innovations through. They turn negative turbulence into positive turbulence, and that positive turbulence creates atmospheres for innovation. ${ }^{19}$

Legacies are left in the hearts of followers, and Cowan's leadership has made an impact on many people. This article is not meant to paint Cowan as a saint. He has flaws like all leaders do, and made many mistakes throughout his journey. His former employees endearingly refer to his awkward mannerisms as "Kevin-isms" and still laugh at some of his blunders. He made no grandiose speeches, has not written a book spouting his leadership theories, and has not trumpeted his successes to anyone. This article is the first attempt at documenting his legacy, the most difficult aspect of which was getting his permission to let the author publish it.

Cowan was not a loud-mouthed, outwardly charismatic leader who promoted himself whenever he got the chance. He was a quiet, unassuming leader who affected things from the inside and let numerous other people get the credit for it. He served the people around him and is regarded as a miracle worker by the people the author spoke with who witnessed this turnaround. His legacy may not be well-known, but it is hoped that this article inspires other researchers or biographers to delve deeper into his legacy, or the legacies of other great Canadian leaders. There are probably many other servant leaders like Cowan, but they need to be uncovered and studied. The world does not need another book or article about Jack Welch or about the leadership failures of millionaire Wall Street leaders. It does, however, need more stories about the true servant leaders that are too busy serving and leading innovative change to promote themselves. Leaders like Kevin Cowan.

\section{Disclosure}

The author completed this project as a project for his doctoral program. The author currently works for Covenant Health in the Human Resources Department. SMHC merged with ten other Catholic organizations to form Covenant Health in 2009. The author has worked with Kevin Cowan on various projects since 2009 but was not employed by the organization during Cowan's tenure as CEO. Information cited above is publicly known or was cited appropriately. No internal documents were used in the compilation of this paper.

\section{References}

1. Henein A, Morisette F. Made in Canada Leadership: Wisdom from the Nation's Best and Brightest on Leadership Practice and Development. Mississauga, ON: John Wiley and Sons; 2007:5.

2. Greenleaf RK. The Servant as Leader. Westfield, IN: Greenleaf Center for Servant Leadership; 1970.

3. Blanchard K, Hodges P. The Servant as Leader: Transforming Your Heart, Head, Hands and Habits. Nashville, TN: J Countryman; 2003.

4. St Michael's Hospital Nurses Alumnae. Out of the Blue: History of St Michael's School of Nursing, Laboratory and X-ray, 1953-1973. Lethbridge, Alberta: Graphcom Printers; 1985.

5. Cameron J. And Martha Served: History of the Sisters of St Martha, Antigonish, Nova Scotia. Halifax, Nova Scotia: Nimbus Publishing; 2000.

6. Shurtz D. St Mike's, health region at odds over blame for staff layoffs. The Lethbridge Herald. September 4, 1998;Sect A:1.

7. Shurtz D. St Mike's cuts from the top; more slashing to be done. The Lethbridge Herald. September 24, 1998; Sect A:1.

8. Gauther G. Deficit, upkeep are challenges facing new St Michael's boss. The Lethbridge Herald. January 12, 2001;Sect A:1.

9. Gallant S. Nurses needed, says union chief. The Lethbridge Herald. Febuary 1, 2001; Sect A:1.

10. Editorial: More nurses a no-brainer. The Lethbridge Herald. Febuary 1, 2001; Sect A:4.

11. Boschman C. St Mike's nurses worried over changes. The Lethbridge Herald. September 15, 2001;Sect A:7.

12. Wynder M. LPNs have a role to play. The Lethbridge Herald. September 24, 2001; Sect A:8.

13. Lacey B, Weaver J, Cowan K. St Michael's Health Centre continues to improve care. The Lethbridge Herald. October 6, 2001;Sect A:4.

14. Sulz D. St Mike's RNs block changes. The Lethbridge Herald. November 1, 2001; Sect A:1.

15. Sakatch S. Nurses fighting staff changes in court. The Lethbridge Herald. October 20, 2001;Sect A:2.

16. Editorial: Seniors' care a complex issue to solve. The Lethbridge Herald. October 20, 2001; Sect A:4.

17. Editorial: 2001 in review. The Lethbridge Herald. December 27, 2001; Sect A:3.

18. United Nurses of Alberta Local 72 versus St Michael's Health Centre and Chinook Health Region. Grievance arbitration award. Febuary 14, $2003 ; 161$.

19. Gryskiewicz SS. Positive Turbulence: Developing Climates for Creativity, Innovation, and Renewal. San Francisco, CA: Jossey-Bass; 1999.

20. Von Krogh G, Ichijo K, Nonaka I. Enabling Knowledge Creation: How to Unlock the Mystery of Tacit Knowledge and Release the Power of Innovation. New York, NY: Oxford University Press; 2000.

21. Lee F. If Disney Ran Your Hospital: 91/2 Things You would do Differently. Bozeman, MT: Second River Healthcare Press; 2004.

22. Amabile TM, Khaire M. Creativity and the role of the leader. Harv Bus Rev. October 2008:100-109. 
23. Arbuckle GA. Healthcare Ministry: Refounding the Mission in Tumultuous Times. Collegeville, MN: Liturgical Press; 2000.

24. Gardner JW. On Leadership. New York: The Free Press; 1990.

25. Collins J. Good to Great: Why some Companies Make the Leap ... and Others Don't. New York: HarperCollins; 2001.

26. De Pree M. Leadership Jazz. The Essential Elements of a Great Leader. New York, NY: Random House; 1992.
27. Anders G. The Rare Find: Spotting Exceptional Talent before Everyone Else. New York, NY: Penguin Group; 2011.

28. Ford L. Transforming Leadership: Jesus' Way of Creating Vision, Shaping Values and Empowering Change. Downers Grove, IL: Intervarsity Press; 1991.

29. Oster G. The Light Prize: Perspectives on Christian Innovation. Virginia Beach, VA: Positive Signs Media; 2011.

\section{Publish your work in this journal}

The Journal of Healthcare Leadership is an international, peer-reviewed, open access journal focusing on leadership for the health profession. The journal is committed to the rapid publication of research focusing on but not limited to: Healthcare policy and law; Theoretical and practical aspects healthcare delivery; Interactions between healthcare and society and evidence-based practices;
Interdisciplinary decision-making; Philosophical and ethical issues; Hazard management; Research and opinion for health leadership; Leadership assessment. The manuscript management system is completely online and includes a very quick and fair peer-review system. Visit http://www.dovepress.com/ testimonials.php to read real quotes from published authors.

Submit your manuscript here: http://www.dovepress.com/journal-of-healthcare-leadership-journal 